\title{
PACK-ICE DRIFT OFF EAST ANTARCTICA AND SOME IMPLICATIONS
}

by

\author{
Ian Allison
}

(Australian Antarctic Division, Kingston, Tasmania 7050, Australia)

\section{ABSTRACT}

Three satellite-tracked data buoys were deployed between $70^{\circ}$ and $80^{\circ} \mathrm{E}$ south of $65^{\circ} \mathrm{S}$ in February-March 1985. These buoys were subsequently trapped within the expanding seasonal sea ice and drifted with the ice. The buoys measured air temperature and pressure, and water temperatures to $100 \mathrm{~m}$ depth. Data from the buoys are used to describe the ice drift and environment within the winter sea-ice zone in this region, both north and south of the Antarctic Divergence. Additional preliminary data from a further six buoys deployed in the same area in March 1987 are also presented.

Besides providing information on the broad-scale drift of the ice in the Prydz Bay region, data from the buoys have shown: (i) the important role that ice drift plays in determining the autumn and winter expansion of Antarctic sea ice; (ii) the highly mobile nature of the ice, even hundreds of kilometres from the ice edge; (iii) the role that ocean-bottom topography has in determining ice drift over the continental shelf; and (iv) the modifying influence that an ice cover has on regional climate.

A qualitative assessment is made of the relative importance of the major forces driving the ice, although the data are insufficient for a detailed study of the ice dynamics.

\section{INTRODUCTION}

Although satellite data obtained over the last 15 years have greatly improved our knowledge of the extent and concentration of Antarctic sea ice, there are few surface observations of pack-ice characteristics and processes within most of the Antarctic seasonal sea-ice zone. In the largely divergent Antarctic sea-ice zone, ice movement is thought to play an important role in determining the overall interaction between high-latitude ocean and atmosphere. Ice drift and deformation vary the ice-thickness distribution and thus modify energy exchanges. Drift transport can also result in a spatial variability in the surface-heat exchange. For example, ice may freeze at one location and be transferred to another where it melts; this results in regions where the net growth over an annual cycle is non-zero.

Gordon and Taylor (1975) suggested that the rapid expansion of Antarctic sea-ice extent in winter was due to a divergent Ekman transport in the upper layer of the ocean, advecting the ice northward. New ice forms in the interior of the ice pack and, at the maximum extent, this is balanced by melting at the northern boundary. Gordon (1981) estimated that the northward ice transport across $60^{\circ} \mathrm{S}$ resulted in a poleward heat flux of almost $10^{14} \mathrm{~W}$ for each metre of ice thickness. Hibler and Ackley (1982) also showed the importance of ice advection in determining the ice edge in the Weddell Sea.

Similarly, ice advection results in a net transport of salt. The equatorward transport of ice in the Antarctic increases the stability of the ocean surface layer where relatively fresh ice melts, and increases salinity in areas of net ice production. The decreased stability in areas of ice production may result in convection penetrating the relatively warm saline upper layers of circumpolar deep water, and cause a significant heat flux into the surface layers and eventually into the atmosphere. Ice drift is therefore important in considering the climatic roles of sea ice. This paper presents ice-drift data, measured by drifting buoys, for the Indian and Pacific Ocean sectors of the Southern Ocean $\left(20^{\circ}\right.$ to $\left.160^{\circ} \mathrm{E}\right)$. In this region, the sea-ice extent varies seasonally from about $1 \times 10^{6} \mathrm{~km}^{2}$ (February) to about $6.3 \times 10^{6} \mathrm{~km}^{2}$ (September-October) (Zwally and others, 1983). The greatest seasonal and inter-annual variability in ice extent in this region occurs in Prydz Bay $\left(70-80^{\circ} \mathrm{E}\right)$ and in the western sector bordering on the Weddell Sea (Lemke and others, 1980). The satellite microwave data presented by Zwally and others (1983) indicate an average ice concentration within the ice edge at the time of maximum extent of about $75 \%$, and shipboard observations near $60^{\circ} \mathrm{E}$ showed a similar average concentration (Jacka and others, 1987). The latter observations, however, showed that much of the ice in October was young (typically less than $0.4 \mathrm{~m}$ thick), thus indicating the dynamic and generally divergent nature of the pack in the region.

Pack ice drifts with ocean currents and is additionally forced by wind stress, water drag, Coriolis force, and the force due to internal ice stress arising from collisions and friction between floes. At time-scales longer than $1 \mathrm{~d}$, inertial forces are unimportant and, away from the coast where stress gradients within the ice can be large, the principal terms in the momentum balance are ice and water stress, Coriolis force, and ocean currents. Hibler and Tucker (1979) showed from empirical model studies that ocean current was unimportant in determining day-to-day ice drift in the Arctic compared to wind forcing but that for velocities averaged over a year and longer currents have a significant effect. Thorndike and Colony (1982) used the FGGE data buoy set for the Arctic Ocean to show that on short time-scales more than $70 \%$ of the variance of ice velocity away from the coast was due to geostrophic wind variations but that at a time-scale of several months half the average ice motion was due to the mean ocean circulation.

BROAD-SCALE SURFACE-OCEAN CIRCULATION AND SEA-ICE DRIFT IN ANTARCTIC WATERS

The large-scale surface-ocean circulation in the circumpolar Southern Ocean is primarily wind driven. Close to the Antarctic coast, and south of the low-pressure trough, winds are predominantly easterly and the mean current is to the west (the East Wind Drift). The Antarctic Divergence in the transition region between the east and west winds occurs at $70-71^{\circ} \mathrm{S}$ north of the Ross Sea, $68-69^{\circ} \mathrm{S}$ in the Weddell Sea, and at $62-63^{\circ} \mathrm{S}$ in the Indian Ocean sector (Deacon, 1982). North of the Divergence the flow is to the east, asscciated with the Antarctic Circumpolar Current and driven by prevailing westerlies. The strength of the eastward-moving flow increases from the Divergence to a maximum at the Polar Front. In the Indian Ocean sector, between $30^{\circ}$ and $90^{\circ} \mathrm{E}$, the Polar Front occurs between about $46^{\circ}$ and $52^{\circ} \mathrm{S}$ (Taylor and others, 1978) and the near-surface speed of the Antarctic Circumpolar Current is greater than $0.5 \mathrm{~m} \mathrm{~s}^{-1}$ (Hofmann, 1985). Ageostrophic Ekman transport results in a northward component of surface drift which is a maximum at the Polar Front. In the East Wind Drift, Ekman transport results 
in coastal convergence which is reflected in the observation that many icebergs stay close to the coast and do not initially disperse northward.

The broad eastward surface flow north of the Antarctic Divergence and westward flow to the south are connected most notably in the Weddell Sea, where a clockwise gyral circulation is induced by the barrier of the Antarctic Peninsula. Zverev (1963) suggested that circulation in the sector between $20^{\circ}$ and $100^{\circ} \mathrm{E}$ consists of a series of large gyres centred on the divergence zone, rather than a continuous westward drift, and from the trajectories of 17 icebergs deployed with transponders and tracked via positioning satellites, Tchernia and Jeannin (1984) have identified a number of regions around Antarctica of northward transport. These include the Weddell and Ross Seas, and the regions around $90^{\circ}$ and $160^{\circ} \mathrm{E}$. There is very little vertical stratification in much of the winter water on the Antarctic continental shelf, with resultant low baroclinicity, and hence bottom topography influences even surface flow. All the regions identified by Tchernia and Jeannin are associated with bathymetric features.

For the Arctic Ocean, there are many data on sea-ice drift from trapped ships, scientific stations on ice islands, and extensive data-buoy networks, but there are few comparable data for Antarctic sea ice. The only large-scale investigations prior to 1985 of Antarctic ice drift have been in the Weddell Sea where drift tracks are available from the ice-bound vessels Endurance (1915-16) and Deutschland (1912) (Ackley, 1979a, 1981) and from data buoys deployed in 1978 and in 1980 (Ackley, 1979b; Ackley and Holt, 1983). Further buoy arrays were deployed in the Weddel Sea during the Winter Weddell Sea Project 1986 (Wadhams and others, 1989) and in the East Antarctic sector in the ANARE program described below.

The drift of Antarctic ice undoubtedly has a major influence on the mass budget of the pack and, particularly because of the generally divergent flow around Antarctica, affects ice extent and ice concentration and hence the ocean-atmosphere energy balance. There are also biological implications to the ice drift. Antarctic sea ice contains significant concentrations of diatoms, algae, and nutrients, and rich populations of krill, squid, fish, birds, and marine mammals are found within the sea-ice zone. The generally circumpolar uniformity of the Antarctic biota may be due in part to large-scale drift of the ice.

\section{DATA-BUOY MEASUREMENTS OF SEA-ICE DRIFT}

The data discussed here are from drifting data buoys deployed in the Prydz Bay region of the Indian Ocean sector of the Southern Ocean. Water-mass characteristics and ocean circulation in this region have been discussed by Smith and others (1984). The ICEX buoys used were designed and manufactured by the $\mathrm{Chr}$. Michelson Institutt, Bergen, Norway, and are similar to those used by Vinje and Steinbakke (1976) but with the addition of a $100 \mathrm{~m}$ thermistor chain for measurement of water temperature at depths of $1,2,3,5,10,20,30,40,50,75$, and $100 \mathrm{~m}$. Other sensors measured atmospheric pressure, the "surface"water temperature (at the base of the hull, about $0.35 \mathrm{~m}$ depth), and the air temperature beneath a vented shield at the top of the buoy. Data were relayed via the Argos System on NOAA/TIROS N satellites.

Three buoys deployed early in 1985 operated successfully within the sea ice, despite the severe conditions they experienced. Unlike Arctic buoys, which are generally deployed on existing ice floes, these buoys were deployed in open water and were subject to both freezing pressure and collision between floes. Table I outlines the operation of the buoys. ICEX41 failed after 7 months, while in a region of very heavy ice, and was presumably crushed as it had shown no previous transmitter faults or deterioration in battery voltage. Both ICEX42 and 43 operated for more than 1 year, although they drifted outside the seasonal ice zone, and these buoys failed due to battery exhaustion. Both buoys were heard intermittently on dates later than shown in Table I but with unusable data.

TABLE I. OPERATIONAL HISTORY OF BUOYS

\begin{tabular}{|c|c|c|c|c|c|c|c|}
\hline $\begin{array}{l}\text { ICEX buoy } \\
\text { number }\end{array}$ & $\begin{array}{c}\text { Argos } \\
\text { ID }\end{array}$ & $\begin{array}{l}\text { WMO } \\
\text { number }\end{array}$ & $\begin{array}{l}\text { Start } \\
\text { date }\end{array}$ & $\begin{array}{l}\text { Initial } \\
\text { position }\end{array}$ & $\begin{array}{l}\text { Stop } \\
\text { date }\end{array}$ & $\begin{array}{c}\text { Final } \\
\text { position }\end{array}$ & $\begin{array}{c}\text { Days } \\
\text { operation }\end{array}$ \\
\hline 41 & 1166 & 56526 & $\begin{array}{l}22 \text { Feb. } \\
1985\end{array}$ & $\begin{array}{l}68^{\circ} 00^{\prime} \mathrm{S} \\
73^{\circ} 00^{\prime} \mathrm{E}\end{array}$ & $\begin{array}{l}28 \text { Sep. } \\
1985\end{array}$ & $\begin{array}{l}67^{\circ} 09^{\prime} \mathrm{S} \\
27^{\circ} 58^{\prime} \mathrm{E}\end{array}$ & 219 \\
\hline 42 & 1167 & 56527 & $\begin{array}{l}2 \text { Mar. } \\
1985\end{array}$ & $\begin{array}{l}65^{\circ} 30^{\prime} \mathrm{S} \\
70^{\circ} 00^{\prime} \mathrm{E}\end{array}$ & $\begin{array}{l}30 \text { Apr. } \\
1986\end{array}$ & $\begin{array}{r}52^{\circ} 05^{\prime} \mathrm{S} \\
114^{\circ} 23^{\prime} \mathrm{E}\end{array}$ & 425 \\
\hline 43 & 1168 & 56528 & $\begin{array}{l}2 \text { Mar. } \\
1985\end{array}$ & $\begin{array}{l}65^{\circ} 30^{\prime} \mathrm{S} \\
76^{\circ} 00^{\prime} \mathrm{E}\end{array}$ & $\begin{array}{l}30 \text { Jun. } \\
1986\end{array}$ & $\begin{array}{r}60^{\circ} 16^{\prime} \mathrm{S} \\
129^{\circ} 51^{\prime} \mathrm{E}\end{array}$ & 486 \\
\hline 44 & 1161 & 56526 & $\begin{array}{l}8 \text { Mar. } \\
1987\end{array}$ & $\begin{array}{l}68^{\circ} 00^{\prime} \mathrm{S} \\
73^{\circ} 00^{\prime} \mathrm{E}\end{array}$ & $\begin{array}{l}\text { After } \\
31 \text { Dec. } \\
1987\end{array}$ & $\begin{array}{c}61^{\circ} 31^{\prime} \mathrm{S} \\
177^{\circ} 34^{\prime} \mathrm{W}\end{array}$ & $299+$ \\
\hline 45 & 1162 & 56527 & $\begin{array}{l}7 \text { Mar. } \\
1987\end{array}$ & $\begin{array}{l}68^{\circ} 00^{\prime} \mathrm{S} \\
78^{\circ} 00^{\prime} \mathrm{E}\end{array}$ & $\begin{array}{l}\text { After } \\
31 \mathrm{Dec} . \\
1987\end{array}$ & $\begin{array}{l}64^{\circ} 50^{\prime} \mathrm{S} \\
24^{\circ} 20^{\prime} \mathrm{E}\end{array}$ & $300+$ \\
\hline 46 & 1163 & 56528 & $\begin{array}{l}9 \text { Mar. } \\
1987\end{array}$ & $\begin{array}{l}66^{\circ} 00^{\prime} \mathrm{S} \\
68^{\circ} 00^{\prime} \mathrm{E}\end{array}$ & $\begin{array}{l}\text { After } \\
31 \text { Dec. } \\
1987\end{array}$ & $\begin{array}{r}64^{\circ} 03^{\prime} \mathrm{S} \\
117^{\circ} 55^{\prime} \mathrm{E}\end{array}$ & $298+$ \\
\hline 47 & 1164 & 56529 & $\begin{array}{l}15 \text { Mar. } \\
1987\end{array}$ & $\begin{array}{l}66^{\circ} 00^{\prime} \mathrm{S} \\
73^{\circ} 30^{\prime} \mathrm{E}\end{array}$ & $\begin{array}{l}20 \text { Mar. } \\
1987\end{array}$ & $\begin{array}{l}65^{\circ} 36^{\prime} \mathrm{S} \\
74^{\circ} 22^{\prime} \mathrm{E}\end{array}$ & 5 \\
\hline 48 & 1165 & 56530 & $\begin{array}{l}9 \text { Mar. } \\
1987\end{array}$ & $\begin{array}{l}67^{\circ} 00^{\prime} \mathrm{S} \\
68^{\circ} 00^{\prime} \mathrm{E}\end{array}$ & $\begin{array}{l}\text { After } \\
31 \text { Dec. } \\
1987\end{array}$ & $\begin{array}{l}61^{\circ} 24^{\prime} \mathrm{S} \\
21^{\circ} 25^{\prime} \mathrm{E}\end{array}$ & $298+$ \\
\hline 49 & 1166 & 56531 & $\begin{array}{l}15 \text { Mar. } \\
1987\end{array}$ & $\begin{array}{l}66^{\circ} 00^{\prime} \mathrm{S} \\
77^{\circ} 30^{\prime} \mathrm{E}\end{array}$ & $\begin{array}{l}\text { After } \\
31 \text { Dec. } \\
1987\end{array}$ & $\begin{array}{r}62^{\circ} 46^{\prime} \mathrm{S} \\
179^{\circ} 12^{\prime} \mathrm{E}\end{array}$ & $292+$ \\
\hline
\end{tabular}


The sensors on the buoys gave generally good quality data, although an instability in the thermistor chain interface meant that these temperature sensors had an accuracy only of $0.2-0.3^{\circ} \mathrm{C}$ rather than the design specification of $0.05^{\circ} \mathrm{C}$. The sea-surface and thermistorchain temperature sensors had a lower limit of $-2^{\circ} \mathrm{C}$ and were out of range if frozen into ice. All buoys were designed to update their readings every hour but the actual update interval for ICEX42 was only $45 \mathrm{~min}$, while for ICEX43 it was $3 \mathrm{~h} 14 \mathrm{~min}$. Transmissions from the buoys were coded according to the WMO standard drifting-buoy code (DRIBU), and data from the buoys was input directly into the Global Telecommunication System.

Figure 1 shows the total drift track of each buoy from 2 March 1985 until it failed. In open water, the $100 \mathrm{~m}$ thermistor chain effectively acted as a drogue on the buoys.

Buoy ICEX41 moved out of Prydz Bay in the East Wind Drift and maintained a generally westward drift throughout its life. Comparison of the drift track with the U.S. Navy/NOAA Joint Ice Center (JIC) ice charts shows that this buoy was near to the ice edge or in the marginal ice zone from mid-March 1985 and that by mid- to late May it was trapped deep within the pack. The buoy remained within $100-200 \mathrm{~km}$ of the coast and from early June onwards was always at least $250 \mathrm{~km}$ and up to $1000 \mathrm{~km}$ from the northern ice edge in ice of $9-10 / 10$ concentration. Despite being deep within the interior pack, the buoy displacement was as much as $50 \mathrm{~km} / \mathrm{d}$ (near $40^{\circ} \mathrm{E}$ on 7 June) (Fig. 2), and the average daily displacement between $40^{\circ}$ and $36^{\circ} \mathrm{E}$ was $22 \mathrm{~km} / \mathrm{d}$ (standard deviation $\pm 15 \mathrm{~km})$.

Bagryantsev and others (1984) estimated the eastward drift of sea ice in this region from the mean monthly pressure field, and obtained mean monthly drifts of 20-30 km/d. Ono and others (1985) used NOAA 7 Advanced Very High-Resolution Radiometer (AVHRR) data received at Syowa to estimate ice drift of up to $32 \mathrm{~km} / \mathrm{d}$ in this region in August 1983. Their 1983 AVHRR data also showed strong shear deformation in Lützow-Holmbukta, which is reflected in the cyclonic gyre shown by the 1985 buoy drift, and also in the drift of a non-drogued FGGE buoy in this region in 1979 (Tchernia and Jeannin, 1983). This circulation is possibly a permanent feature associated with Gunnerus Bank, extending north from Riiser-Larsen Peninsula at $34^{\circ} \mathrm{E}$ (Fig. 1). However, it does not show clearly in the drift of tracked icebergs of $200 \mathrm{~m}$ or more draught (Tchernia and Jeannin, 1983). The AVHRR data show that the westward-moving pack ice between $45^{\circ}$ and $40^{\circ} \mathrm{E}$ is separated from $100 \mathrm{~km}$ of fast ice by a $10 \mathrm{~km}$ "shore" lead.

ICEX42 and ICEX43 also initially drifted westward but for most of the winter period their overall drift was to the north. In mid-March, ICEX41 and 42 were only $65 \mathrm{~km}$ apart, but they subsequently took very different tracks. From comparison with the JIC charts, ICEX42 remained close to or at the ice edge between April and the beginning of October but drifted free of the ice into the Antarctic Circumpolar Current as the ice edge started to retreat. ICEX43 was within the marginal ice zone from mid-March and was trapped deeper within the pack by mid-April. By October, this buoy also drifted free of the ice and moved eastward in the Antarctic Circumpolar Current, at a latitude about $5^{\circ}$ further south than ICEX42. ICEX43 drifted east at $60 \mathrm{~S}$ for the first half of 1986 and failed about 1 month before the 1986 ice cover expanded to that latitude.

\section{DISCUSSION OF THE RESULTS FROM THE ICEX BUOYS}

The autumn and winter expansion of ice extent

A notable feature of the drift of all buoys was that for a considerable time they maintained a position at the ice edge, or in the outer part of the marginal ice zone, as the ice edge advanced northward. Figure 3 shows the drift track of the buoys relative to the ice edge, as determined by the U.S. Navy/NOAA Joint Ice Center (JIC). Only the outermost ice edge is shown. JIC charts usually show ice concentrations of $9-10 / 10$ in the interior of the winter pack

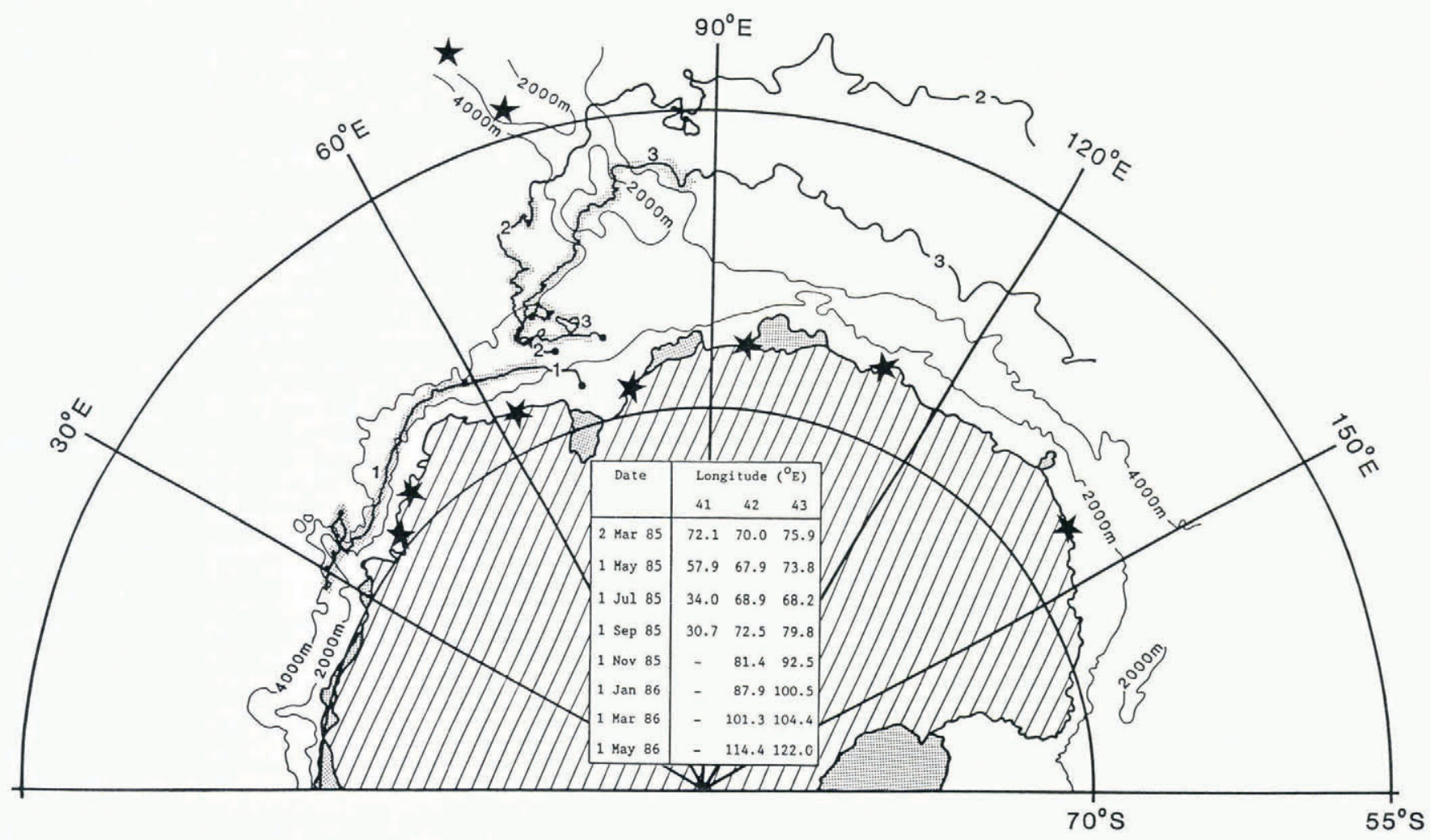

Fig. 1. Drift tracks of data buoys deployed in Prydz Bay in February-March 1985. Numbers on the tracks are the last digit of the buoy (e.g. $1=$ ICEX41). Stippled tracks indicate those periods when the buoys were within the sea-ice edge as shown on the JIC weekly ice charts. The position of the buoys along the tracks is indicated by the inset table. Also shown are meteorological stations $(*)$ and the 2000 and $4000 \mathrm{~m}$ bathymetric contours. 

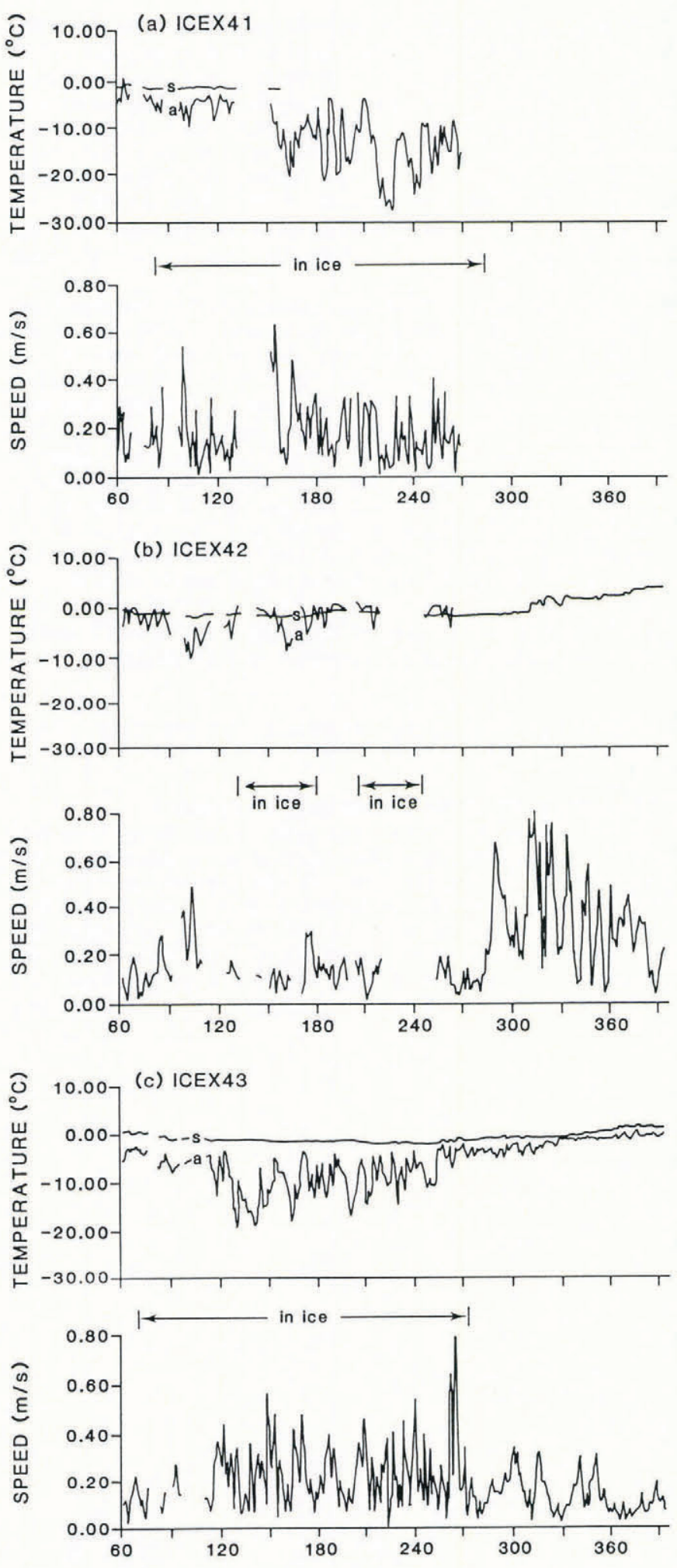

DAY NUMBER

Fig. 2. Mean daily sea-surface $(s)$ and air temperatures $(a)$, and buoy-drift velocity for ICEX41, ICEX42, and ICEX43 during 1985. The indicated periods show when the buoys were within the ice edge as mapped by the JIC.

(although Zwally and others (1983) contended that the concentrations are considerably lower) and a marginal ice zone, up to several hundred kilometres wide at the outer edge, of $4-6 / 10$ concentration. Initially, all three buoys kept close to the ice edge or within the marginal ice zone and advanced at the same rate as the ice edge. ICEX41 became trapped within the interior pack around late May, and ICEX43 around mid-April, but ICEX42 stayed near the ice edge throughout the period of ice advance. Particularly, this last drift track suggests strong dynamic control in determining the Antarctic ice extent, with the ice-edge
- Position of ICEX41

- Position of ICEX42

- Position of ICEX43

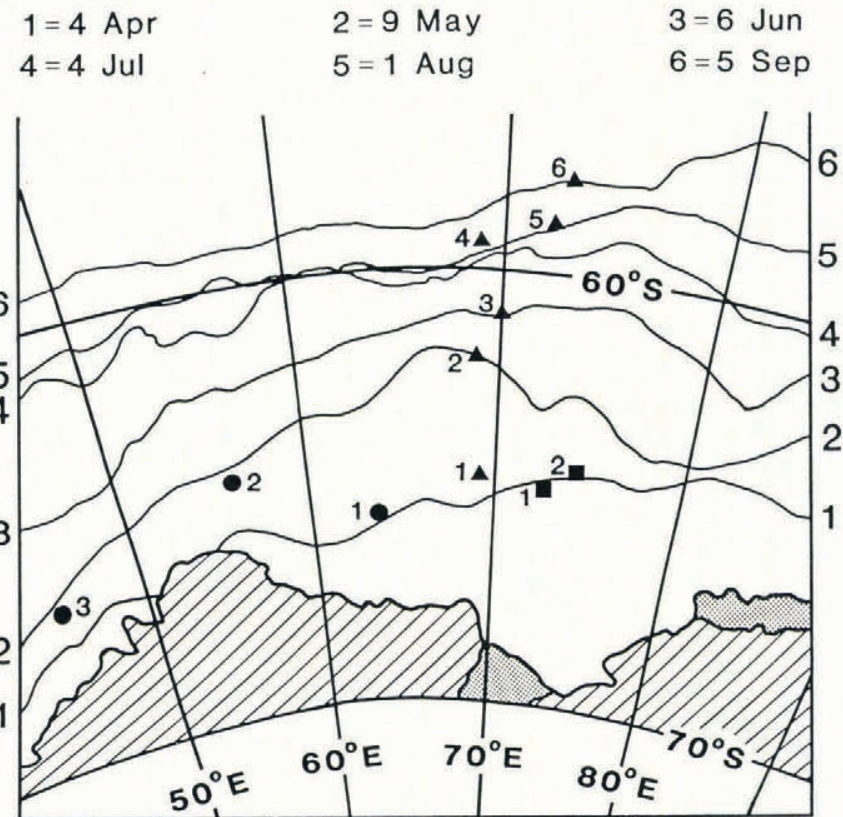

Fig. 3. Position of drifting buoys relative to the JIC ice edge on indicated dates during the 1985 expansion of the ice cover.

position resulting from a divergent advection of ice and enhanced ice production further south. Hibler and Ackley (1982) showed that ice drift is also important in determining the seasonal cycle of the ice-edge position in the Weddell Sea, but their model results suggested that there the expansion to maximum is largely thermodynamic and ice advection is most important during the retreat phase.

The September and early October drift of ICEX42 to the north-east (Figs 1 and 3 ) was also coincident with the advance of a tongue of ice to $55^{\circ} \mathrm{S}$ at $80^{\circ} \mathrm{E}$. The ice at this longitude of ten has a relatively more northerly extent, which is probably related to the cyclonic gyre circulation in Prydz Bay (Smith and others, 1984).

Atmospheric and oceanic temperatures within the sea-ice zone

Daily mean values of air temperature $(a)$ and surfacewater temperature $(s)$ are shown in Figure 2. The air temperatures measured by the buoys were strongly related to the nature of the surroundings as determined from the JIC charts. In ice of $9-10 / 10$ concentration (ICEX41 days 150270; ICEX43, days 110-260), air temperatures were typically below $-10^{\circ} \mathrm{C}$, with large day-to-day variability, but in lower-concentration ice in the marginal ice zone or near the ice edge (ICEX41 days 80-150; ICEX42 days 100-250; ICEX 43 days $70-110$ ) the presence of open water modified the air temperatures which stayed relatively constant at about $-5^{\circ} \mathrm{C}$. To the north of the sea-ice edge, the mean air temperatures remain generally above $-2^{\circ} \mathrm{C}$.

The surface-water temperature sensor, which was out of range below $-2{ }^{\circ} \mathrm{C}$, also provided confirmation of periods when the buoys were frozen solidly into ice. From day 70 to 100 the surface temperature measured by ICEX 41 dropped steadily from $-0.5^{\circ} \mathrm{C}$ to the freezing point and by day 140 (late May) the buoy was frozen into the ice and the surface temperature was lower than the sensor limit. Surface temperatures measured by ICEX 43 dropped steadily from $0.2^{\circ} \mathrm{C}$ to the freezing point between early March and the end of April, and thence remained at the freezing point while the buoy was in high-concentration ice but apparently not actually frozen into a floe. ICEX 42 generally remained near the ice edge and the surface-water temperature was generally close to freezing except in July (days 180-210) when it drifted up to $50 \mathrm{~km}$ north of the ice edge and recorded temperatures as high as $-0.5^{\circ} \mathrm{C}$ at all depths to $100 \mathrm{~m}$. 
(a) ICEX 41
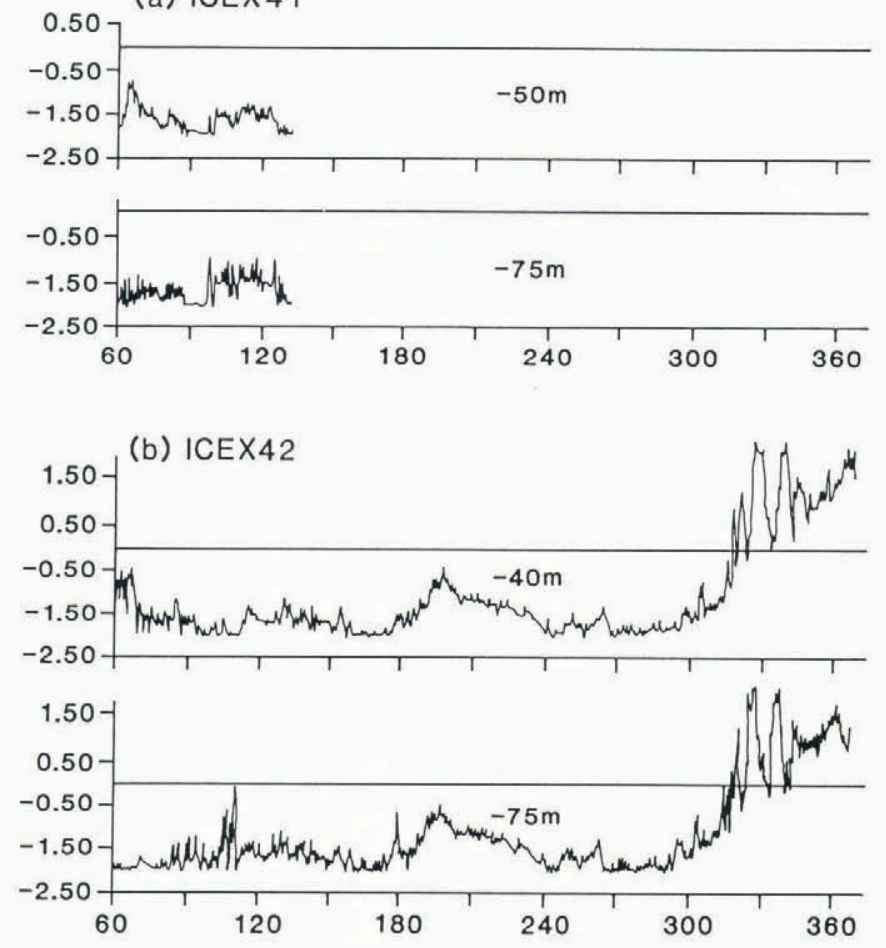

(c) ICEX43
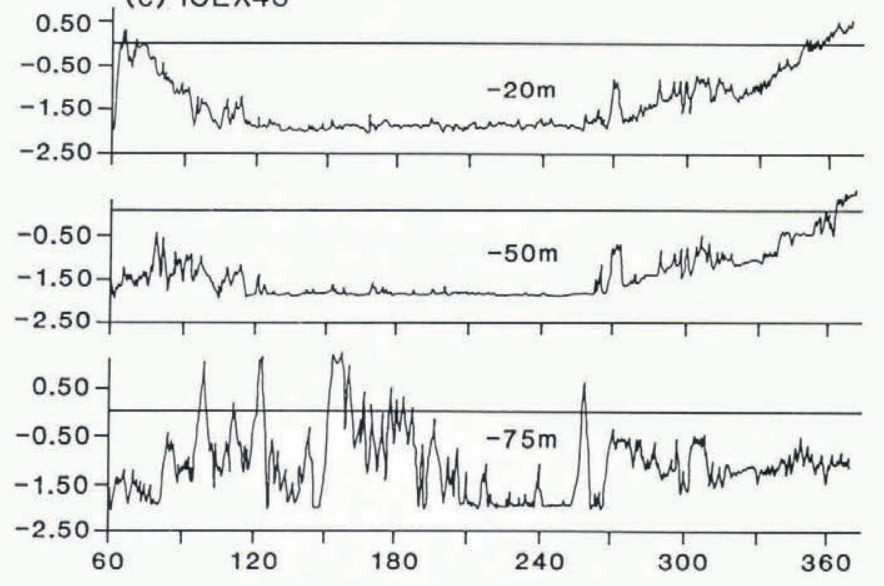

DAY NUMBER

Fig. 4. Ocean temperatures $\left({ }^{\circ} \mathrm{C}\right)$ measured by the buoys during 1985 at depths above and below the summer thermocline.

Figure 4 shows selected sub-surface temperatures measured by the buoys. The presence at depths between 40 and $75 \mathrm{~m}$ of a summer thermocline, which broke down in March and April due to surface cooling and thermohaline convection induced by ice growth, is evidenced in the data from all buoys. The sub-surface temperatures during winter months were generally isothermal to at least $75 \mathrm{~m}$ depth. Between days 100 and 130, ICEX41 passed through an area where water temperatures at all levels to $100 \mathrm{~m}$ depth were $0.2-0.3^{\circ} \mathrm{C}$ above freezing. From both ICEX 42 and 43 data there is evidence of oceanic fronts north of the ice edge. ICEX43 showed a temperature increase at all depths of $1^{\circ} \mathrm{C}$ just north of the ice edge near $57^{\circ} \mathrm{S}, 85^{\circ} \mathrm{E}$, where the buoy reached open water in late September, and between 10 and 20 November (days 304-324) ICEX42 drifted north through a strong oceanic front at $54^{\circ} \mathrm{S}, 87^{\circ} \mathrm{E}$ and temperatures at all depths increased by about $2.5^{\circ} \mathrm{C}$.

The relationship between ice motion and wind

The daily drift speed (the distance made good in $24 \mathrm{~h}$ ) of buoys between March 1985 and the end of January 1986 is shown in Figure 2. Drift speed was calculated from the displacement between $00.00 \mathrm{Z}$ positions and hence a tidal component of motion cannot be resolved. There is a noticeable difference in the pattern of drift speed between periods when the buoys were within the sea-ice zone and when they were north of the ice in the Antarctic Circumpolar Current (after day 280 for ICEX42 and ICEX43). In the sea-ice zone, the buoy drift showed a high day-to-day variability resulting from the wind forcing of the pack, whereas in the Antarctic Circumpolar Current the speed of the drogued buoys varied only slowly over periods of $10 \mathrm{~d}$ or more, possibly associated with meanders in the current. There was a strong increase in the mean strength of the ACC from $0.16 \mathrm{~m} / \mathrm{s}$ at about $60^{\circ} \mathrm{S}$ (ICEX43) to $0.33 \mathrm{~m} / \mathrm{s}$ at $50{ }^{\circ} \mathrm{S}$ (ICEX42). From the drift of numerous FGGE buoys, Hofmann (1985) determined a mean value of the current in the Polar Front core at these longitudes of nearly $0.5 \mathrm{~m} / \mathrm{s}$.

No directly measured wind speeds are available at the buoy positions but the buoy drift has been compared with the $1000 \mathrm{hPa}$ geostrophic wind analyses for the Southern Hemisphere produced by the Australian Bureau of Meteorology. These winds, on an approximate $500 \mathrm{~km} \times$ $500 \mathrm{~km} \mathrm{grid,} \mathrm{were} \mathrm{computer-derived} \mathrm{from} \mathrm{hand-analysed}$ mean sea-level pressure and thickness fields for the Southern Hemisphere. The daily wind speeds and wind heading were calculated by two-dimensional linear interpolation of the $1000 \mathrm{hPa}$ geostrophic wind at $11.00 \mathrm{Z}$ from the four grid points surrounding the buoy position. Wind headings rather than wind directions were calculated for compatibility with the buoy data.

It is important to note that the derived wind fields are subject to considerable error because of the scarcity of data at high southern latitudes. Meteorological stations in the region of the buoy drift are shown in Figure 1 and, while additional pressure data were available from drifting buoys, including the ICEX buoys themselves, there was only a total of $10-15$ buoys in the Indian Ocean throughout 1985 and the great majority of these were north of $50^{\circ} \mathrm{S}$. Further down-grading of the wind data occurs due to the coarseness of the grid and in the computer derivation of the $1000 \mathrm{hPa}$ heights and geostrophic winds.

Three different situations were considered in examining the relationship between wind and buoy drift. These were when

i. The buoy was locked into heavy-concentration ice $(9-10 / 10)$ ice and moving with the ice.

ii. The buoy was in lower-concentration ice $(6-8 / 10)$ in the marginal ice zone (MIZ) or near the ice edge and the buoy drift was probably largely, but not completely determined by the movement of ice floes.

iii. The buoy was outside the sea-ice zone and with the thermistor chain acting as an effective drogue, the buoy drifted with the near-surface current.

The buoys were broadly assigned to these categories for different periods on the basis of the JIC ice charts and the temperature records from the buoys themselves.

For all buoys and all situations there was no significant statistical correlation between wind speed and buoy speed on a day-to-day basis. However, when the buoy was in sea ice (heavy pack or the MIZ), there was good correlation $\left(r^{2} \sim 0.65\right.$ for all buoys) between the wind heading and the drift heading (Table II). The lack of correlation between daily displacement and wind speed is undoubtedly due to poor wind data rather than to the wind stress being unimportant in the momentum balance of the ice. Satellite imagery ensures that pressure systems in the Southern Hemisphere analyses are generally shown in the correct position, if not of the right magnitude, and hence the wind direction and ice drift showed good day-to-day correlation. North of the seasonal ice zone, the buoy drift showed no correlation with either wind speed or direction since the buoy moved with the surface current.

Figure 5 shows the mean daily drift heading plotted against wind heading for days when the buoys were within the sea-ice zone. The easterly drifting pack (buoy headings of $45-135^{\circ}$ ) generally moved $30-40^{\circ}$ to the left of the wind, as would be expected from Ekman divergence. In heavy pack moving westward $\left(225-315^{\circ}\right)$, however, the ice tended to drift to the right of the wind. This ice was in the East Wind Drift and close to the coast where the flow 
TABLE II. BUOY-DRIFT SPEED AND RELATIONSHIP BETWEEN BUOY AND WIND HEADING

\begin{tabular}{|c|c|c|c|c|c|}
\hline & $\begin{array}{l}\text { Average } \\
\text { distance } \\
\text { made } \\
\text { good }\end{array}$ & $\begin{array}{l}\text { Mean } \\
\text { vector } \\
\text { buoy } \\
\text { speed }\end{array}$ & $\begin{array}{l}\text { Mean } \\
\text { vector } \\
\text { buoy } \\
\text { heading }\end{array}$ & $\begin{array}{l}\text { Mean } \\
\text { vector } \\
\text { wind } \\
\text { heading }\end{array}$ & $\begin{array}{l}\text { Coefficient } \\
\text { of correlation } \\
(r) \text { between } \\
\text { daily buoy } \\
\text { heading and } \\
\text { wind heading }\end{array}$ \\
\hline & $\mathrm{km}$ & $\mathrm{km} / \mathrm{d}$ & deg & deg & \\
\hline $\begin{array}{l}\text { ICEX } 41 \\
\text { MIZ } \\
(01 / 03 / 85-19 / 05 / 85)\end{array}$ & 16.3 & 11.2 & 277 & 308 & 0.81 \\
\hline $\begin{array}{l}9-10 / 10 \text { ice } \\
(20 / 05 / 85-27 / 09 / 85)\end{array}$ & 14.3 & 5.8 & 269 & 241 & 0.83 \\
\hline $\begin{array}{l}\text { ICEX } 42 \\
\text { MIZ } \\
(03 / 03 / 85-07 / 10 / 85)\end{array}$ & 11.0 & 4.0 & 44 & 87 & 0.79 \\
\hline $\begin{array}{l}\text { Open ocean } \\
(08 / 10 / 85-30 / 01 / 86)\end{array}$ & 28.3 & 12.4 & 70 & 84 & 0.22 \\
\hline $\begin{array}{l}\text { ICEX } 43 \\
\text { MIZ } \\
(03 / 03 / 85-30 / 04 / 85)\end{array}$ & 15.3 & 7.2 & 276 & 332 & 0.81 \\
\hline $\begin{array}{l}9-10 / 10 \text { ice } \\
(01 / 05 / 85-12 / 09 / 85)\end{array}$ & 19.8 & 8.0 & 32 & 61 & 0.83 \\
\hline $\begin{array}{l}\text { Open ocean } \\
(13 / 09 / 85-30 / 01 / 86)\end{array}$ & 13.9 & 9.8 & 96 & 92 & 0.37 \\
\hline
\end{tabular}

would be expected to be convergent and where internal ice forces are also important in the overall momentum balance. The current speed in this region, as indicated by iceberg drift (Tchernia and Jeannin, 1983), is about $5-10 \mathrm{~km} / \mathrm{d}$.

The vector mean-drift speed of ICEX41 for the full period of data was $0.087 \mathrm{~m} / \mathrm{s}$ (a daily displacement of $7.5 \mathrm{~km}$ ) and of ICEX42 and 43 when in ice $0.046 \mathrm{~m} / \mathrm{s}$ $(4.0 \mathrm{~km})$ and $0.090 \mathrm{~m} / \mathrm{s}(7.8 \mathrm{~km})$, respectively. Ackley $(1981)$ measured long-term mean drift in the Weddell Sea of

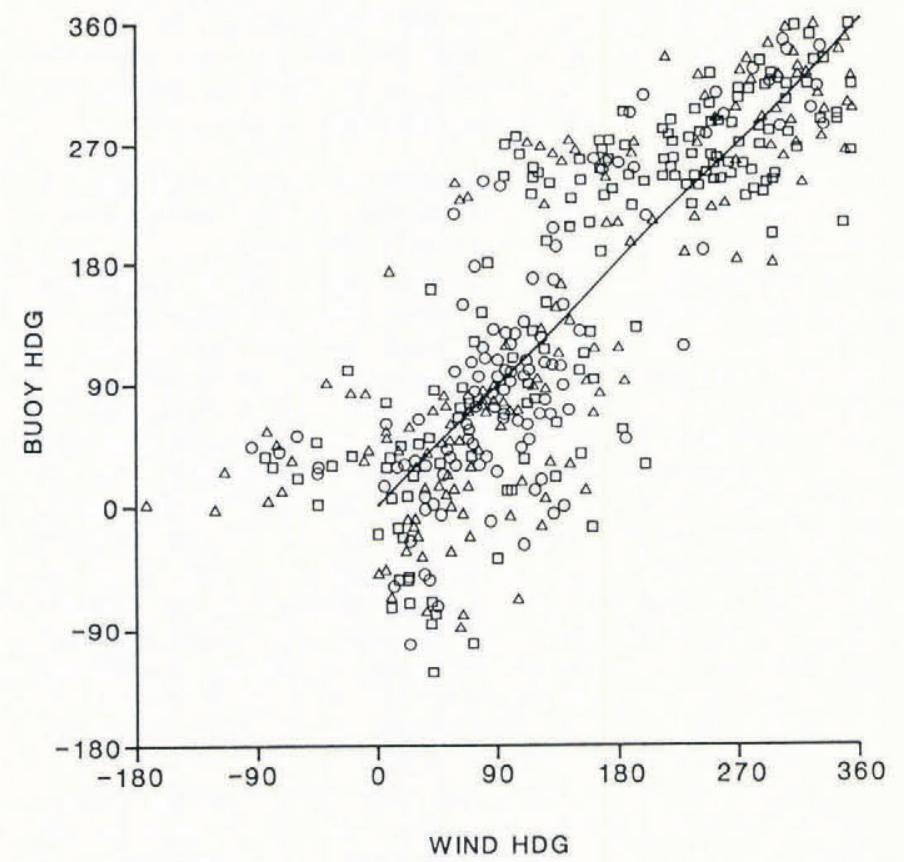

Fig. 5. Buoy heading compared to geostrophic wind heading for days when buoys were within the ice field. Points above the solid line indicate that the buoys were moving to the right of the geostrophic wind and vice versa. ICEX41, squares; ICEX42, circles; ICEX43, triangles.
$3-4 \mathrm{~km} / \mathrm{d}$. In ice, the average buoy-drift speed was 2.5$3.5 \%$ of the average geostrophic wind speed except for the drift of ICEX41 in the southern part of Prydz Bay. Here, the buoy moved at greater than $10 \%$ of the wind speed, possibly indicating the strength of the gyral ocean circulation.

\section{PRELIMINARY DATA FROM 1987 BUOYS}

A further six ICEX buoys, without thermistor chains but with $100 \mathrm{~m}$ drogue ropes, were deployed in Prydz Bay in March 1987. One buoy failed shortly after launch but the others were still transmitting at the end of 1987: Table I outlines the operation of these buoys. Figure 6 shows the drift tracks of the 1987 buoys until 1 November 1987. In 1987, the ice cover was later in forming than in 1985 and only the two buoys in the East Wind Drift (ICEX45 and 48) became trapped for any period within the sea ice. Nonetheless, data from these buoys do support the 1985 results.

The three buoys that moved northward $(44,46$, and 49) remained $100-200 \mathrm{~km}$ north of, but a constant distance ahead of, the advancing ice edge until they reached $57^{\circ}$ to $58^{\circ} \mathrm{S}$. The northward drift of the 1985 buoys at the ice edge might be explained by ice-buoy interaction (the advancing ice edge pushes the buoys northward) but in 1987 the buoys were well clear of the ice, and the parallel advance of the buoys and the ice edge suggests rather that the rate of ice advance is determined largely by the surface drift. Although deployed at different locations, ICEX44 and 49 came close together in April and maintained very similar drift tracks from then on. The three buoys drifted eastward about $200-300 \mathrm{~km}$ from the ice edge. Note that in both 1985 and 1987 the buoys in the Antarctic Circumpolar Current tend to move southward again as the ice edge retreats. Although not shown in Figure 6, by mid-November 1987 ICEX46 had drifted far enough south to be moving again westward.

Both ICEX 45 and 48 remained in the East Wind Drift and became trapped in the ice for part of their life-time. These buoys showed high westerly drift speeds between $70^{\circ}$ and $30^{\circ} \mathrm{E}$ but slowed down markedly to the west of $30^{\circ} \mathrm{E}$ as they approached the Weddell Sea. As in 1985, there was 


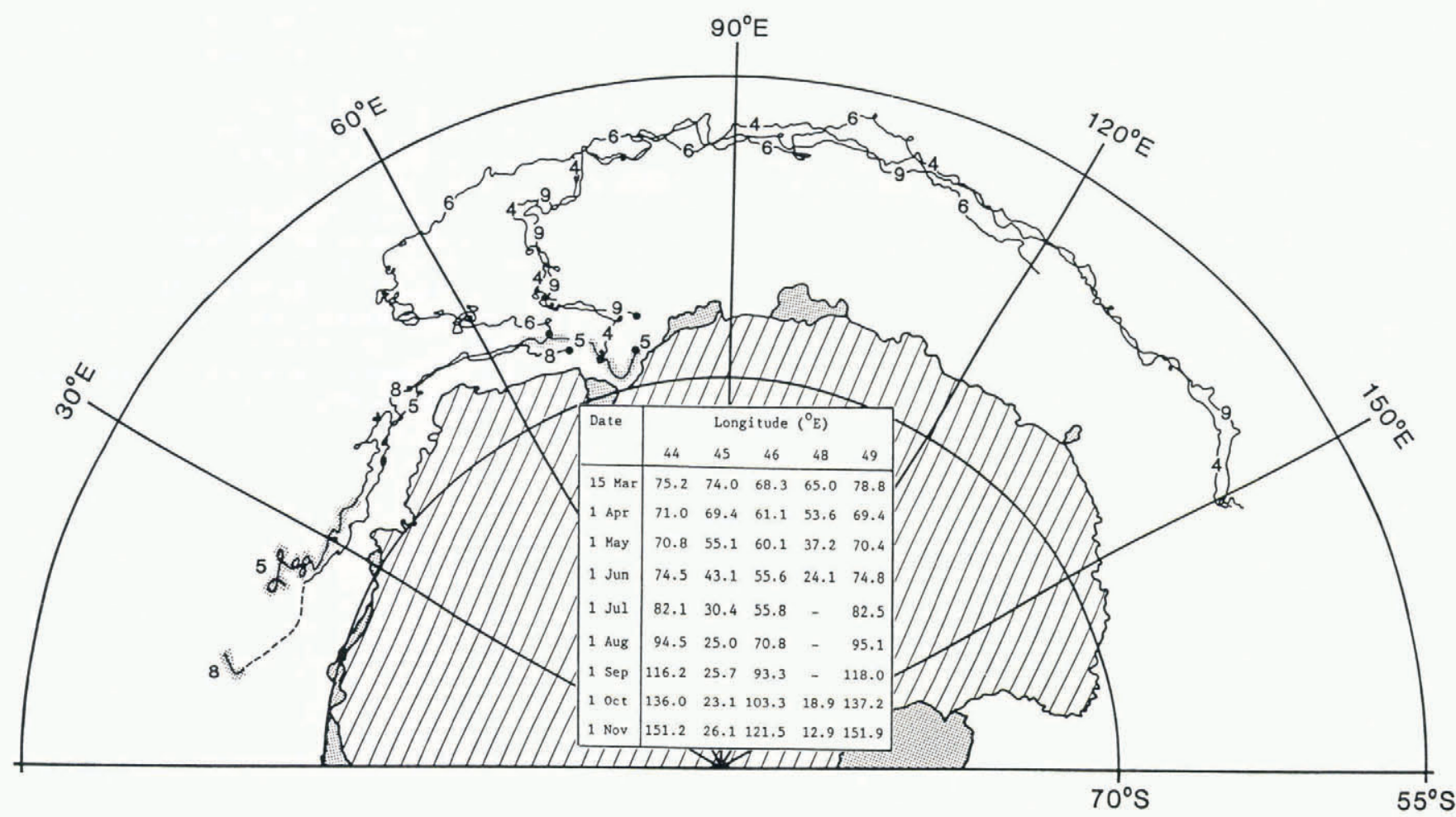

Fig. 6. Drift tracks up to 1 November 1987 of data buoys deployed in Prydz Bay in March 1987. Stippled tracks indicate periods when the buoys were within the JIC ice edge. (See caption to Figure 1 for further details.)

very little difference between the early position in Prydz Bay of those buoys that eventually moved north of the Antarctic Divergence and those that remained to the south.

All 1987 buoys showed similar average drift speeds to those of the 1985 buoys, suggesting that the long-term ice drift can be largely explained in terms of mean ocean circulation, whereas the day-to-day variability results from wind stress.

\section{CONCLUSIONS}

Results from the 1985 and 1987 buoys demonstrate or further confirm a number of important features regarding the East Antarctica sea-ice zone. These are that:

even in 9-10/10 concentration ice, drift speeds are high;

for ice moving generally eastward, the day-to-day drift variability is determined largely by the wind. In the westward moving ice, however, where convergence along the coast might be expected, other driving forces are also important;

the autumn and winter advance of the ice edge parallels and is largely controlled by the northward surface drift;

particularly in the East Wind Drift, bottom topography influences surface-flow direction;

the air temperatures in the sea-ice zone are strongly influenced by the presence and extent of open water; the summer thermocline over the continental shelf, which is typically at $50-75 \mathrm{~m}$ depth, breaks down by the end of April to an isothermal surface-water mass.

\section{ACKNOWLEDGEMENTS}

This paper is dedicated to the memory of MV Nella Dan lost off Macquarie Island, 24 December 1987. During almost 27 years of supporting Antarctic science, Nella Dan and her crew experienced most Antarctic ice conditions and passed on much of that experience to the scientific community. I thank the crew and ANARE expeditioners on board Nella Dan for deploying the buoys, and N. Nergaard, CMI, Bergen, for the buoy design and construction.

\section{REFERENCES}

Ackley, S.F. 1979a. Drifting buoy measurements on Weddell Sea pack ice. Antarct. J. U.S., 14(5), 106-108.

Ackley, S.F. 1979b. Mass-balance aspects of Weddell Sea pack ice. J. Glaciol., 24(90), 391-405.

Ackley, S.F. 1981. Sea-ice atmosphere interactions in the Weddell Sea using drifting buoys. Association of Hydrological Sciences Publication 131 (Symposium at Canberra 1979 - Sea Level, Ice and Climatic change), 171-191.

Ackley, S.F. and E.T. Holt. Unpublished. Sea ice data buoys in the Weddell Sea; 1979-1980. CRREL Technical Note.

Bagryantsev, N.V., and 6 others. 1984. Some aspects of sea ice studies and modelling in the context of climate research. In Report of the Meeting of Experts on Sea Ice and Climate Modelling. Appendix H. Geneva, WMO.

Deacon, G.E.R. 1982. Physical and biological zonation in the Southern Ocean. Deep-Sea Res., 29, 1-16.

Gordon, A.L. 1981. Seasonality of Southern Ocean sea ice. J. Geophys. Res., 86(C5), 4193-4197.

Gordon, A.L. and H.W. Taylor. 1975. Seasonal change of Antarctic sea ice cover. Science, 187(4174), 346-347.

Hibler, W.D., III and S.F. Ackley. 1982. On modeling the Weddell Sea pack ice. Ann. Glaciol., 3, 125-130.

Hibler, W.D., III and W.B. Tucker, III. 1979. Some results from a linear-viscous model of the Arctic ice cover. $J$. Glaciol., 22(87), 293-304.

Hofmann, E.E. 1985. The large-scale horizontal structure of the Antarctic Circumpolar Current from FGGE drifters. J. Geophys. Res., 90(C4), 7087-7097.

Jacka, T.H., I. Allison, R. Thwaites, and J.C. Wilson. 1987. Characteristics of the seasonal sea ice of East Antarctica and comparisons with satellite observations. Ann. Glaciol., 9, 85-91.

Lemke, P., E.W. Trinkl, and K. Hasselmann. 1980. Stochastic dynamic analysis of polar sea ice variability. $J$. Phys. Oceanogr., 10(12), 2100-2120.

Ono, N., T. Yamanouchi, and H. Ohuma. 1985. Characteristics of shore openings in winter sea ice off Enderby and Queen Maud lands, East Antarctica. In IAMAP/IAPSO Joint Assembly, August 1985, Honolulu. Abstract volume, 99.

Smith, N.R., Dong Zhaoqian, K.R. Kerry, and S. Wright. 1984. Water masses and circulation in the region of Prydz 
Bay, Antarctica. Deep-Sea Res., 31, 1121-1147.

Taylor, H.W., A.L. Gordon, and E. Molinelli. 1978. Climatic characteristics of the Antarctic Polar Front Zone. J. Geophys. Res., 83(C9), 4572-4578.

Tchernia, P. and P.F. Jeannin. 1983. Quelques aspects de la circulation océanique Antarctique révélés par l'observation de la dérivé d'icebergs (1972-1983). Paris, Museum National d'Histoire Naturelle.

Tchernia, P. and P.F. Jeannin. 1984. Circulation in Antarctic waters as revealed by iceberg tracks 1972-1983. Polar Rec., 22(138), 263-269.

Thorndike, A.S. and R. Colony. 1982. Sea ice motion in response to geostrophic winds. J. Geophys. Res., 87(C8), 5845-5852.
Vinje, T.E. and P. Steinbakke. 1977. Nimbus-6 located automatic stations in the Svalbard waters in 1975. Nor. Polarinst. Arbok 1975, 109-117.

Wadhams, P., C.B. Sear, D.R. Crane, M.A. Rowe, S.J. Morrison, and D.W.S. Limbert. 1989. Basin-scale ice motion and deformation in the Weddell Sea during winter. Ann. Glaciol., 12, 178-186.

Zverev, A.A. 1963. Techeniya Indiyskom sektore Antarktiki [Currents in the Indian sector of the Antarctic]. Tr. Sov. Antarkt. Eksped., 17, 144-155.

Zwally, H.J., J.C. Comiso, C.L. Parkinson, W.J. Campbell, F.D. Carsey, and P. Gloersen. 1983. Antarctic sea-ice, 1973-1976: satellite passive-microwave observations. Washington, DC, National Aeronautics and Space Administration. (NASA SP-459.) 